\title{
Challenges concerning argumentative writing in a second language context
}

May Olaug Horverak

University of Agder

\begin{abstract}
The current study is based on parts of the data collected in a quasi-experiment conducted in four English classes of Norwegian upper secondary school students. The purpose of the quasiexperiment was to explore whether a teaching intervention based on systemic functional linguistics and genre-pedagogy would support students in improving their competence in writing argumentative texts in English. The improvement was measured by comparing evaluations of pre-and post-tests. The current study investigates what seemed to be the main challenges for Norwegian students concerning this type of genre in a second language context based on the pre-tests and the evaluations of the pre-tests. The most challenging aspect seems to be how to write thorough argumentation and discussion and to use sources in an independent and correct manner. Other challenging features seem to be how to structure texts and how to adjust the language to appropriate levels of formality and modality. To meet these challenges, this article advocates introducing genre-pedagogy as a teaching approach in ESLcontexts (English as a second language). This would ensure a focus on how to construct arguments through detailed instruction and to adjust the writing to purpose and situation.
\end{abstract}

KEYWORDS: second language writing, argumentative writing, challenges, genre-pedagogy

\section{INTRODUCTION}

Written speech is a separate linguistic function, differing from oral speech in both structure and mode of functioning. (Vygotsky, 2012, first published in 1962, p. 98)

As Vygotsky points out, written language is different from spoken language, and this implies that learners of a second language might have different challenges with learning how to write compared with learning how to speak. In his corpus-studies, Biber points out that there are differences in complexity level and involvement among others (1988). When learning how to 


\section{Nordic Journal of Modern Language Methodology}

write different types of texts, students need to learn what the appropriate level of involvement is and how to construct sentences and text. As pointed out by Shaw and Weir, writing is a complex process, particularly in a second language context. This process includes several cognitive processes such as planning, organisation, translation and revising (Shaw \& Weir, 2007). The focus of the current study is on what challenges Norwegian students have when writing argumentative texts in English at the beginning of the first year of their upper secondary school studies.

English has quite a special status in Norway, as it is unclear whether it should be regarded a second language or a foreign language. Even though it is considered a second language in the educational system (Norwegian Directorate for Education and Training, 2006), it is not an official language in Norway like it is in other countries where it is regarded as a second language (Graddol, 2006). Instead, it could be said to have an in-between status as neither a foreign nor a second language (Graddol, 1997; Rindal, 2012; Rindal \& Piercy, 2013). Although Norwegians generally have quite a high proficiency in English (Education First, 2012), studies show that young Norwegian learners struggle more with writing than with understanding and speaking English (Bonnet, 2004). This is confirmed by results from English exams in Norwegian lower secondary school during showing that Norwegian pupils score lower on written than on oral exams (Norwegian Directorate for Education and Training, 2014). Studies from higher education also show that Norwegian students' English writing skills are inadequate (Lehmann, 1999; Nygaard, 2010). As there is an increased need for good English skills in higher education and in various professions (Hellekjær, 2007, 2010), it is important that students are prepared for this.

With the Knowledge Promotion of 2006 in Norway came an emphasis on developing basic skills in the curricula of the Norwegian educational system, among these writing skills, with a focus on adjusting to purpose and situation (Norwegian Directorate for Education and Training, 2013a). This is in line with recommendations developed by the European Parliament and the Council of the European Union about key competences for lifelong learning (European Parliament, 2006). In the English subject curriculum for Norwegian schools, writing competence is specified as "being able to express ideas and opinions in an understandable and purposeful manner...planning, formulating and working with texts that communicate and that are well structured and coherent" (Norwegian Directorate for 


\section{Nordic Journal of Modern Language Methodology}

Education and Training, 2013a). This is reflected in the competence aims for both lower and upper secondary school. It is not specified exactly what type of texts the pupils are supposed to learn, and it is up to the teachers to decide what to prioritise.

Research has shown that argumentative writing is challenging in general in contexts where English is the first language (L1) (Andrews, 1995; Beard, 2000; Freedman \& Pringle, 1988). An extensive study on the quality of Norwegian pupils' L1 writing skills after lower secondary school showed that argumentative writing was also difficult for Norwegian pupils in an L1 context (Berge, Evensen, Hertzberg, \& Vagle, 2005). One of the main challenges was creating coherence in texts and structuring arguments reasonably. Another problem was that they used too much informal language (Berge \& Hertzberg, 2005; Hundahl, 2010).

From Silva's meta-analysis, we see that L2 (second language) writers have more difficulty organising material when they write when compared to L1 writers (1993). They were less effective in linking arguments and when it comes to linking words, they used more simple coordinate conjunctions and fewer subordinate conjunctions and lexical ties. $A$ Synthesis of Research on Second Language Writing in English from 2008 (Leki, Cumming, \& Silva, 2008) compares second language writers of different levels, and reveals that the more proficient L2 writers use more subordinate conjunctions and less coordinating conjunctions than the less proficient L2 writers. Hence, one of the challenging features of learning to write in a second language is to use a variation of linking-words and complex sentences.

The current study focuses on a dataset collected during a quasi-experimental study that tested out the effects of a genre-pedagogical approach to teaching argumentative writing in English in an ESL (English as a second language) context in upper secondary school (Horverak, 2016a). The results of this study showed that students improved from pre- to posttests regardless of first language, gender and what grade they had been given in English previously. The students improved most in the categories using sources, structuring text, and adjusting language to a formal context, elements that were included in the teaching intervention. According to a recent small-scale interview study, these are also issues that teachers perceive as generally challenging for Norwegian upper secondary school students when writing in English (Horverak, 2015). However, there has been little research on students' English writing skills in a Norwegian upper secondary school context, which is the focus of the current study. 


\section{Nordic Journal of Modern Language Methodology}

The research question of this study is: What are the main challenges for Norwegian learners when meeting the demands of argumentative writing in English in the transfer from lower to upper secondary school? To answer this question, the pre-tests from the quasiexperiment, and the evaluations of these, have been investigated with a focus on what aspects of writing seem problematic for the learners. The findings of this study may provide insight into what needs attention in an ESL writing instruction context to help students develop their writing skills, both in upper secondary school and on lower levels.

\section{METHOD}

The current study investigates what is particularly challenging for students concerning argumentative writing in English based on the texts and the evaluations of these texts from 4 upper secondary school classes. The data material consists of 83 student texts written by first year general studies students at the start of their first semester, and evaluations of these texts in the categories structure, content and language on a score from 1 to 6 , with 1 as the lowest and 6 as the highest. Hence, this study combines a quantitative and qualitative analysis. In the following, there is a presentation of the sample, the procedure of data collection and how the data is analysed. The project has been approved by the Data Protection Official for Research (NSD).

\section{Sample}

To recruit classes to the study, I contacted acquaintances, so the participating groups were selected through a kind of convenience sampling. Hence, the participants constitute a nonprobability sample (Cohen, Manion, \& Morrison, 2011). The sample consisted of 28 males (33.7\%) and 55 females (66.3\%). Of these 76 (91.6\%) had Norwegian as a first language, whereas 7 (8.4\%) had another first language. The students' final grades in written English from lower secondary school ranged from 3 to 6 , with the majority receiving the grades 4 and 5 , as illustrated in the box and whisker's plot in figure 1. 


\section{Nordic Journal of Modern Language Methodology}

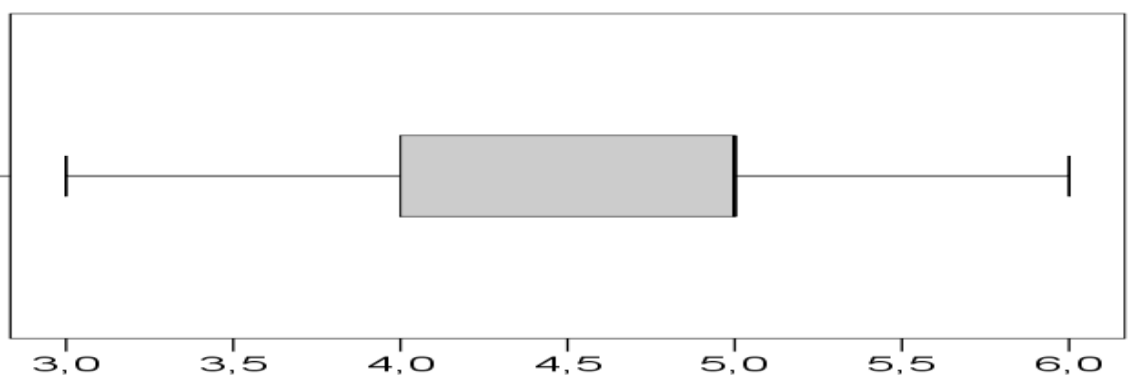

Figure 1: The participants' final grade in written English in lower secondary school.

\section{Procedure of data collection}

Before the teaching intervention in the quasi-experiment started, the students were given a pre-test on the topic of values and social issues in American society. Two relevant text excerpts were attached to the exercise, as it is generally expected that pupils use and refer to sources in written English exams both in lower and upper secondary school. There were 2 different exercises on the same topic with different texts attached. One of the tests was given to two of the classes and the other was given to the two other classes. The difference in the exercises was that in one, they were asked to describe some important values in the USA and discuss them in relation to the situation of various people in modern American society, and in the other, they were asked to describe social issues and discuss these in relation to American values. The attached texts in the first exercise were excerpts from "I Have a Dream" by Martin Luther King and "Gangsta's Paradise" by Coolio. Excerpts included in the second exercise were Obama's inauguration speech of 2009 and "Ghetto Gospel” by Tupac.

The tasks given were based on the ideas of task-based language learning (Byrnes \& Manchón, 2014; Skehan, 1998); the meaning was central in the students' text production, and the students produced their own meanings in relation to a topic from the real world. The students were given a genre-based task, as they were to write a discussion, which is a subcategory of argument in the genre-pedagogical tradition on which the quasi-experiment was based (Rose, 2009). The cognitive demands of the exercises given were equally high as they required students to read, transmit knowledge, reason and discuss. Hence, the task complexity was increased along the resource-directing dimension according to Robinson's model (Robinson, 2001b). The students' prior knowledge on the topic of social issues in the USA and American values may have differed, but it is likely that most of them had some prior knowledge about the USA from lower secondary school. 


\section{Nordic Journal of Modern Language Methodology}

The data was collected at the very start of the semester the first year of upper secondary school to find out what may be problematic in the transfer from lower to upper secondary school concerning argumentative writing in English. No writing instruction was given prior to the test. The students were given 90 minutes to complete the exercise, they used computers, and the only allowed aid for the writing task was dictionaries. There was no specification given regarding requirements of length or number of words. The students were given evaluation criteria adapted from the guidelines for exam censors in English (Norwegian Directorate for Education and Training, 2013b).

\section{Analysis}

The data consists of qualitative data, which was converted into quantitative data through content analysis by scoring the tests with grades from 1 as lowest to 6 as highest (Cohen et al., 2011, p. 564). This corresponded to the grades that were normally given in English. All the tests were evaluated by two of the participating teachers and me as researcher. There was an overall evaluation of the tests, as well as evaluations of the main categories of structure, language and content and of 6 or 7 items in each of these categories (See appendix 1) ${ }^{1}$. The evaluation form used is in accordance with criteria used in examination evaluation guidelines (Norwegian Directorate for Education and Training, 2013b). In the analysis in this study, the results of the total score and the three main categories of evaluation are illustrated by box and whisker plots, giving the interquartile range and the median score.

In addition, the scores on the individual items in each main category are investigated to find out what the most challenging features of argumentative writing are. The items included in the category of structure are how well students can write an introduction, sort ideas into paragraphs, write topic sentences, create coherent arguments, conclude, use connectors and use pronouns as cohesive links. The items included in the category of language were to what extent the spelling and grammar was correct and to what degree there were complex sentence structures, an advanced and varied vocabulary, appropriate formality level and expressions of modality. The items included in the category of content were whether

\footnotetext{
${ }^{1}$ For more details regarding the statistical analysis in the quasi-experiment, see "An experimental study on the effect of systemic functional linguistics applied through a genre-pedagogy approach to teaching writing" (Horverak, 2016a).
} 


\section{Nordic Journal of Modern Language Methodology}

the text answered the question given, how clear the topic for discussion was, to what degree the arguments were relevant, how thorough the argumentation was, to what degree the text included counter-arguments and how well sources were used and how well they were presented in the text and in a literature list. These items are also illustrated by box and whisker plots. All illustrations are based on the mean score of the three raters. To illustrate some of the challenging features of argumentative writing, examples from the students' texts are included. These examples are chosen as they illustrate well the type of problems Norwegian students may have.

\section{RESULTS AND ANALYSIS}

When looking at the distribution of the results of the total scores displayed in figure 2 below, we see that the majority of the students received an average total evaluation around 3 , which is also the median score. We find the majority of the scores from just below 3 to just below 4 on the scale, and the range is from 1 to 5 .

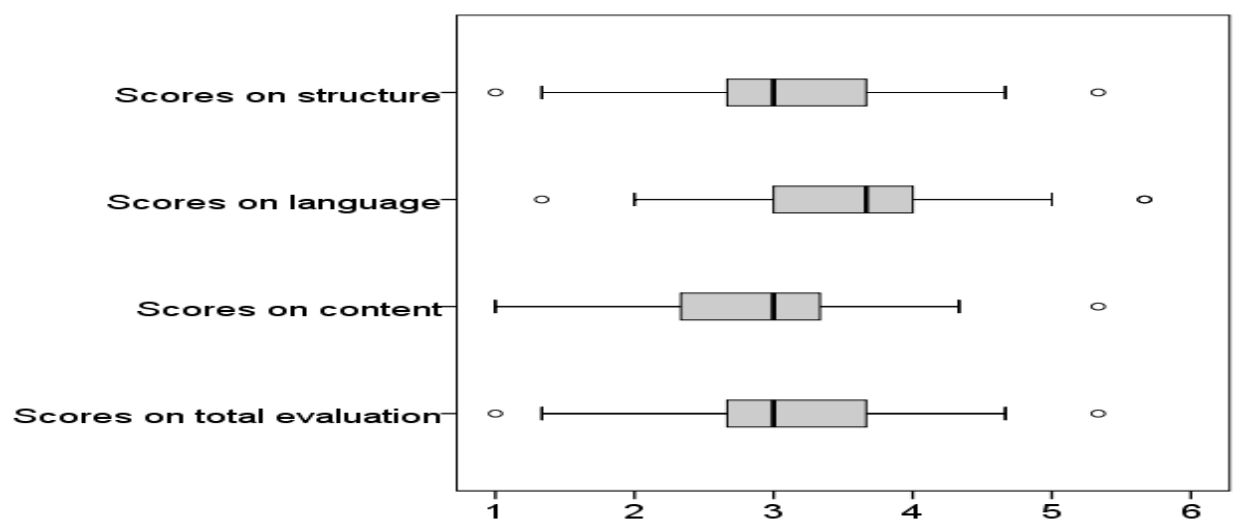

Figure 2. Scores on structure, language and content and total scores.

When looking at the results of each main category in figure 2, we see that many of the students have a score on a rather low level, i.e. below 3 , in the category of content, whereas the majority scores on a middle level between 3 and 4 on language. The score on structure is close to the score on language, just with a lower median. We see that in the two categories of structure and content, $50 \%$ of the students received the evaluation 3 or below, which is similar to the results of the total evaluations. From the illustrations in figure 2, one may conclude that 


\section{Nordic Journal of Modern Language Methodology}

the students in this study struggled more with structure and content than with language when writing argumentative texts.

Moving to which structural features are most challenging for students, we see from the illustration in figure 3 below that there are only subtle differences between the items.

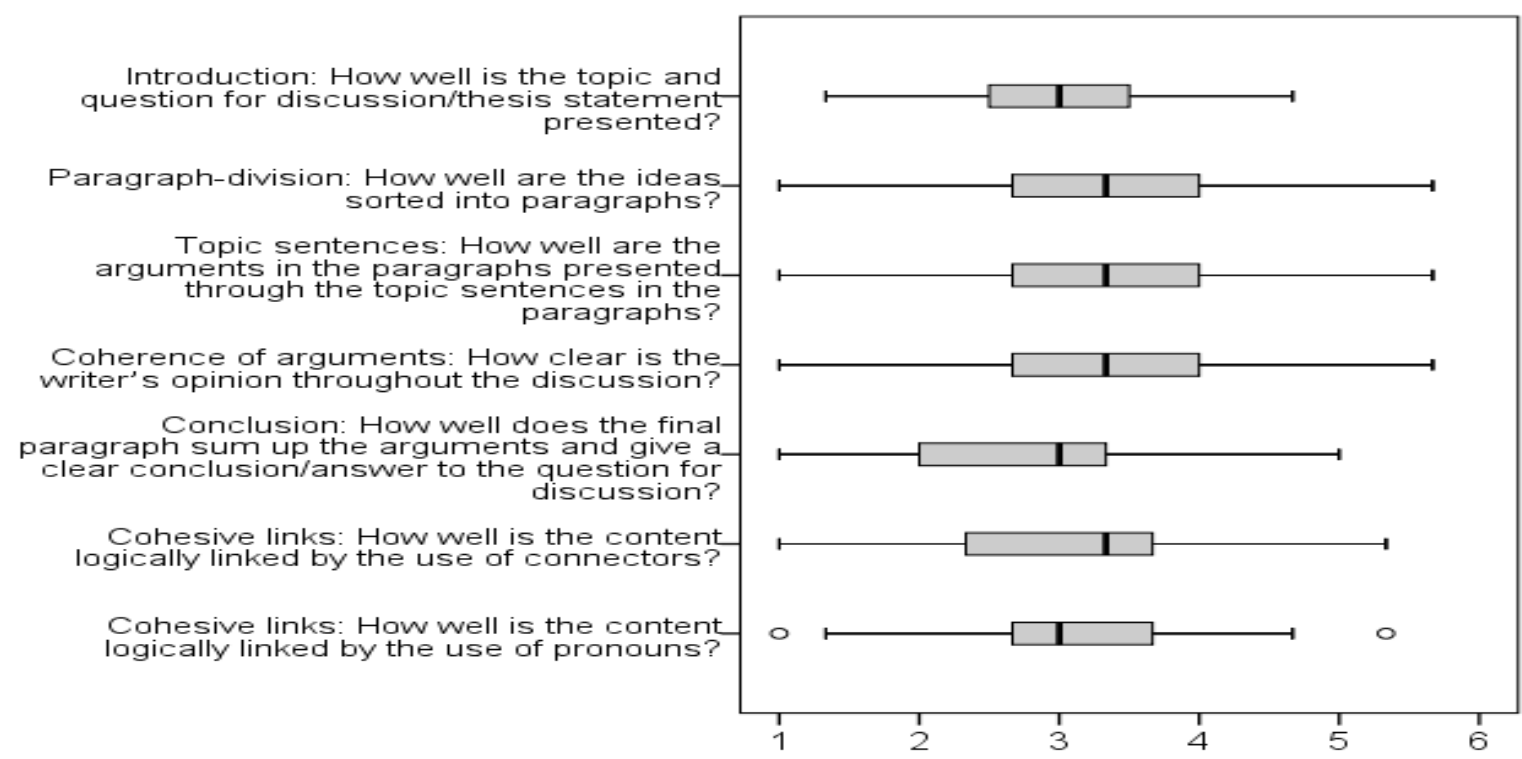

Figure 3. Scores on items in the main category structure.

The feature that has lower scores is whether the students write good conclusions. From the plot, we see that $50 \%$ of the students have a score between 2 and just above 3 on this item. As half of the students have a score from just above 3 and below on all items, one may conclude that all these features are challenging for students.

In the main category of language, there is more variation in the scores on the different items compared with the scores in the category of structure (see figure 4). 


\section{Nordic Journal of Modern Language Methodology}

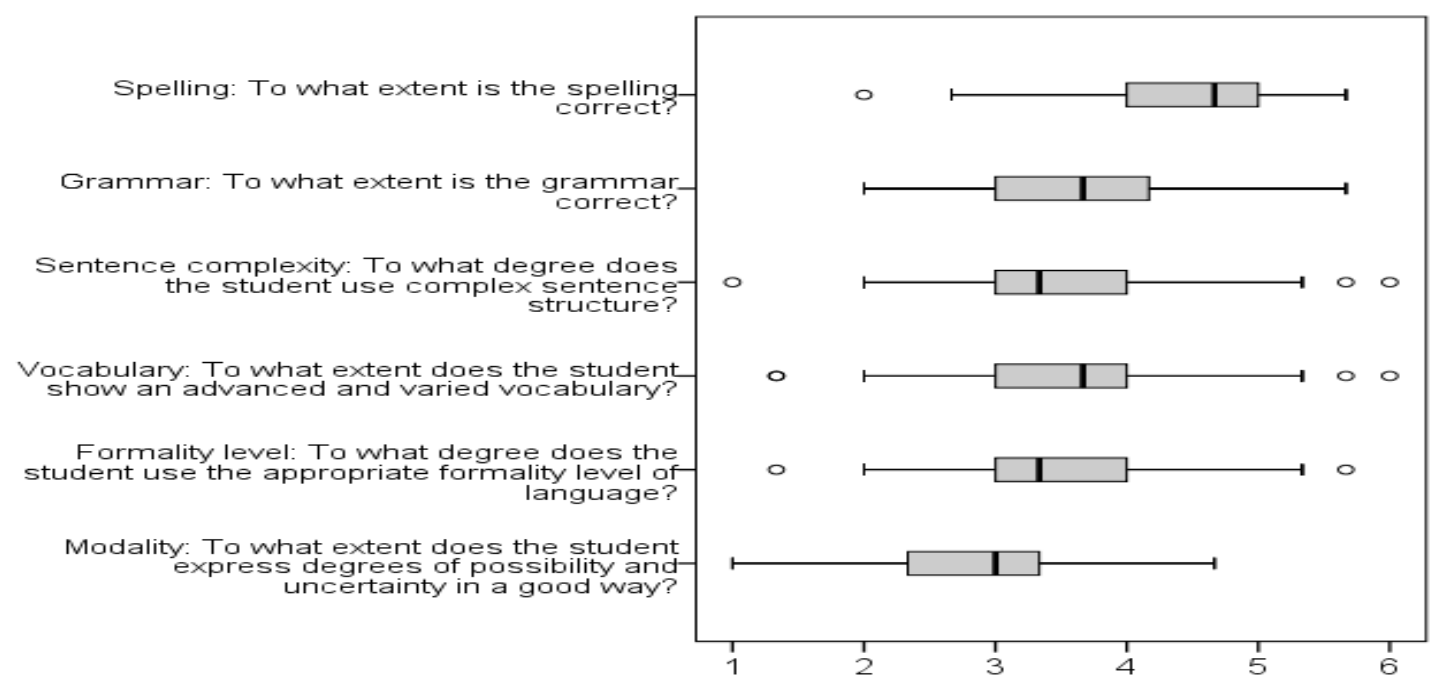

Figure 4. Scores on items in the main category language.

There seems to be little problem with spelling in English, which may be due to the fact that students are allowed to write on computers and use dictionaries. The median score is close to 4 for the categories of whether the grammar is correct and whether the students use an advanced vocabulary. Hence, the majority of the students received rather high evaluations on these items. The most challenging feature seems to be to express modality, more specifically degrees of possibility and uncertainty. On this item, there is a median of 3 , and $25 \%$ received a score between 1 and just above 2 . On all the other items, at least $75 \%$ of the students received the grade 3 and above. On the two items of whether students wrote complex sentences and whether they used appropriate formality level, we see the median is just above 3. About $50 \%$ of the students scored between 3 and 2 on these items, which are rather low scores.

In the final main category, content, we see that using sources and referring to these correctly are the main challenges (Figure 5). 


\section{Nordic Journal of Modern Language Methodology}

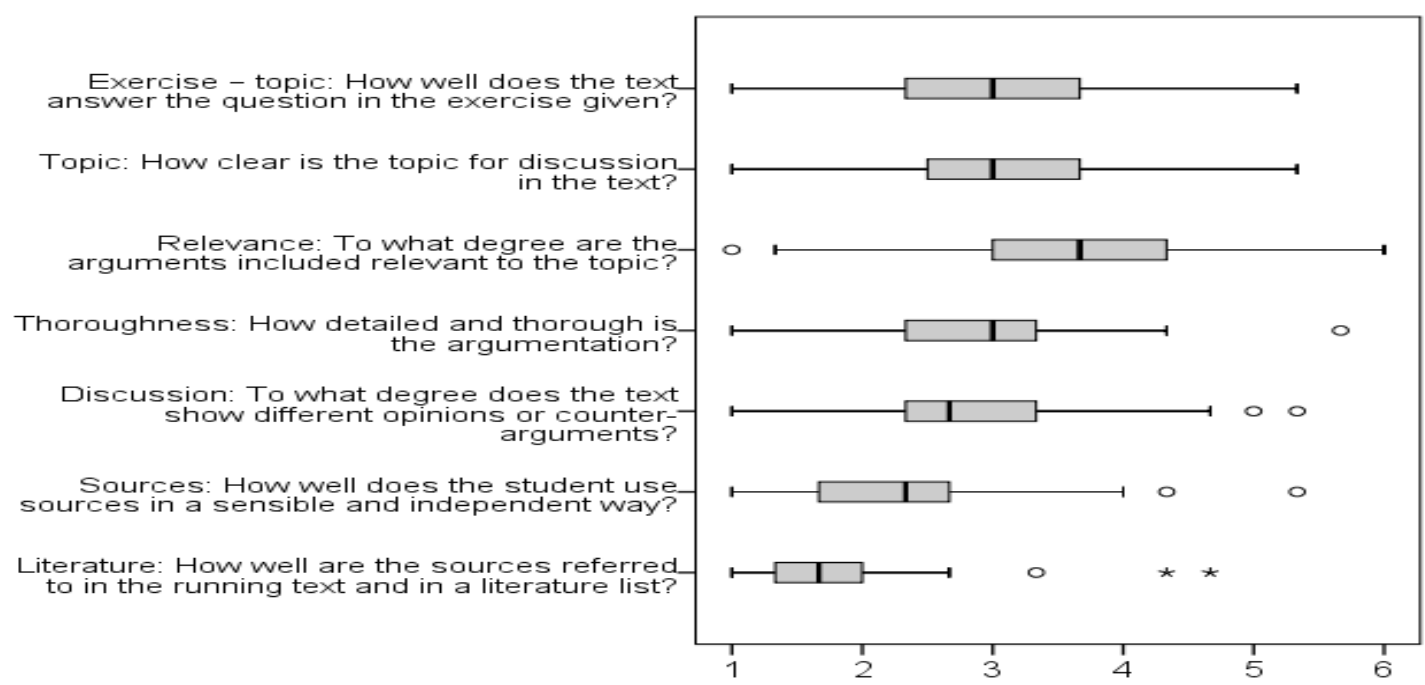

Figure 5. Scores on items in the main category content.

The final item here, whether students refer to sources correctly, has a median score below 2 , and there are just a couple of students that scored over 3 . When it comes to using sources, the scores are just slightly higher with a median score just above 2, and a little more than $75 \%$ getting a score below 3. More than half of the students also score below 3 on whether they present counter-arguments in their texts. The median score is 3 for whether students write a thorough argumentation, whether they answer the question given and whether the topic for discussion included is clear. Very few students have high scores on whether they write thorough argumentation. This may be partly because they do not use the sources much. Quite a few students have ignored the sources completely. Only on the item concerning whether the arguments included are relevant is there a median above 3 , closer to 4 . The results indicate that even though there is some variation displayed, the students generally struggle with writing thorough argumentation including discussions and references to sources.

\section{Examples of challenging features of argumentative writing}

Starting with structure, students have some problems writing clear introductions presenting what they are going to discuss. Often, some facts about the topic are included, which is illustrated in example 1, but there is no clear indication of what will be the focus of the continuing discussion. Often the paragraph division is unclear as well, as we see in example 2 below.

Example 1: 


\section{Nordic Journal of Modern Language Methodology}

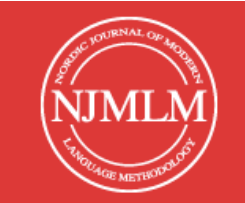

$2018,6(1), 66-85$

In the USA for a couple of years ago, people got judged by the color for their skin. You was not important if you were black. It was own schools, busses and other places for the colored people. If you were a black in the 1960's, you could be hitten or bullied at the street.

Example 2:

USA.

The big hope for so many people. Why?

It is a great place. It is a place where families can live together, where children can grow up. Everything will be fine as long as we get there.

Is it actually like this?

Also in the main body of the texts, the focus of the discussions might be unclear as we see in example 3. This paragraph starts with a question about why America is a rich country, and the concluding sentence states that "fatness" is a big problem. We see that the paragraph division is unclear, as the student has started on a new line at different intervals within the paragraph.

Example 3:

America is a very rich country. Why?

In America, you can see a very big difference between poor and rich. So, when you look at people who are fat, and walks around in ugly clothes. They are poor. Junk food in America is very inexpensive. Often all the poor people goes to the MC Donalds or other junk food stores, and eat dinner.

Therefore is rich people often small, skinny. Because they have money to buy all the healthy food. The payment on the jobs is very low, so people, who do not have so good jobs, cannot live on the money they earn.

Therefore is fatness a very big problem in America.

When it comes to content, example 3 also illustrates the shallowness of argumentation in some texts, as does the following example 4, which constitutes a full answer to the assignment.

Example 4:

\section{Social issues}

What can we do to solve all the social issues? What can we do to make everything better for everyone? And how can we do it?

These questions are Obama and Tupac asking. Social issues is something we can find everywhere at any time. It is much we can do to make it better, but we can`t help everyone. 


\section{Nordic Journal of Modern Language Methodology}

For those who is in the situation where they need help they have to do something back. They have to try to make it better too. If they want to get the problems behind them, they need to help them who are trying to solve their problems.

Obama are saying that if it is something that we want to do, we can do it. Everything is possible.

I think that if everyone does its best we can change a lot.

As many of the other texts, this text includes some relevant aspects from the attached texts without referring properly to them. This student manages to present what the core issue for discussion will be, and to express her opinion. What is missing is more thorough and detailed content throughout, both in the introduction, the body and the conclusion, with illustrating examples from the attached texts. The following example 5 illustrates another shallow conclusion.

Example 5:

I personally thinks that America is a cool country with a lot of history. But I don't like the way the government runs it. I don't like the politicians, and their ideology.

This example also demonstrates the problems some Norwegian students have in adjusting their language to the appropriate formality level. The expression "cool country" does not really fit into this genre, and this student is too personal expressing that he "don't like.." certain features of American society. In examples 6, 7 and 8, other informal features are illustrated. In example 6, the expression "what the hell" certainly does not fit in this type of formal writing. The student follows up with a colloquial style, saying "Do not get me wrong...". In example 7, the expression "bitch" is applied, which is highly inappropriate. In example 8 , we see a very emotional conclusion with a quotation mark underlying the emotional stress of the writer.

Example 6:

And what the hell, when did we stop caring? Why are there not more people spending every days of theirs trying to get these people a roof above their head. Help them get some food, a bottle of water. Do not get me wrong, there are so many inspirational human beings helping other.

Example 7: 


\section{Nordic Journal of Modern Language Methodology}

I can see why you might not like people for being a bitch or mean, but because of their looks? You can decide how you are going to act and how people are going to look at you, but you can't decide how you are going to look.

Example 8:

My opinion about this is that it is terrible! It is not great that people can be treated like that just because of a skin color.

Another challenging feature in the category of language is the use of modal expressions. In example 9, we see how a student expresses quite a prejudiced opinion about people that are not used to living with black people.

Example 9:

Some people aren't used to live side by side with black colored people, and when they do, they have already made up an opinion about them.

Finally, the complexity level of the students' sentences is not very high, and often there is an overuse of the coordinating conjunctions "and" and "but" as we see in example 10.

Example 10:

But for the poor's it is not much in it for them. They don't have money, can't send their kids to school, buy medicine, get a lovely house or live a good life. But the great thing is that the poor people are often very happy, because they find happiness in the small thing and are trying to live a good life anyway. They don't get selfish and they learn to get independent. But they may have to live in the dangerous parts of the streets, the gangster's paradise.

The examples included here illustrate that students do have problems when structuring texts, writing thorough argumentation including using sources to do so, and adjusting the language to the context in terms of modality and formality. Although some of the tests included argumentation based on the sources attached, very few of them included proper referencing and a literature list.

\section{DISCUSSION}

This study set out to investigate what problems Norwegian students have concerning writing argumentative texts in English in the transfer from lower to upper secondary school. Based on the collected material, it seems like structuring and making the arguments thorough by 
referring to sources seem to be problematic features. Other problems revealed are adjusting language to "purpose and situation", as stated in the curriculum, and modifying statements. These are perhaps not surprising findings, as structuring arguments and using an appropriate formal language have also been proven challenging in first language contexts for Norwegian pupils (Berge et al., 2005). However, argumentative writing in general is quite challenging (Andrews, 1995; Beard, 2000; Freedman \& Pringle, 1988); this is not a problem only for Norwegian students. Writing arguments include critical thinking, a skill which needs to be continuously worked upon to be enhanced (Mehta \& Al-Mahrooqi, 2015). When the students wrote the pre-tests, there had been no discussion on the topic in advance, and this may have influenced how well the students succeeded with writing.

Another important aspect is the complexity level of the exercises given. The fact that the task complexity level in the pre-test was increased along the resource-directing dimension (Robinson, 2001b), requiring both information transmission and reasoning, can also have influenced how well the students succeeded with writing. There are different hypotheses concerning what effect task complexity has on students' writing. On the one hand, the Limited Attentional Capacity Model suggests that when the complexity of a task is reduced, the L2 learner will have more capacity to focus on language (Skehan, 1998). On the other hand, the Triadic Componential Framework Model, also called the Cognition Hypothesis, suggests that if the complexity level of the task is increased, the complexity level of the language will increase (Robinson, 2001a). Based on a series of studies in an L2 context, Kuiken and Vedder conclude that the Cognition Hypothesis cannot be confirmed (Kuiken \& Vedder, 2002). A more nuanced picture is given in Ruiz-Funes'study, suggesting that the effect task complexity has on language complexity is dependent on the learners' level of language proficiency (Ruiz-Funes, 2015). She suggests that the more proficient language learners manage to pay attention to linguistic forms while composing texts that require a high level of cognitive attention. The high task-complexity level in the current study may have influenced the students' ability to succeed with writing in English, perhaps in a positive direction for the more proficient learners, perhaps in a negative direction for the less proficient learners.

There are also other challenges with the validity of the findings in this study. The conclusions are based on subjective evaluations of student texts, and other raters may have 


\section{Nordic Journal of Modern Language Methodology}

given different evaluations. There is also just one text from each participant included in the analyses in this study. This is partly why examples are included, to illustrate the challenges reported from the quantitative analyses. In addition, the preliminary interview-study (Horverak, 2015) supports the fact that the challenges reported in this study are what Norwegians struggle with when writing argumentative texts in English, that they struggle with structuring, using sources and adjusting the language to purpose and situation.

Choosing appropriate language is also a challenge for Norwegian students when writing in Norwegian (Berge \& Hertzberg, 2005; Hundahl, 2010). Including expressions like "what the hell", and "bitch" breaks with what type of language is expected in this context. Maybe students use more extreme expressions when using a second or foreign language because they do not actually realise how inappropriate this is. There is a lot of English input in the media that young people are exposed to, and students are used to hearing a great deal of informal language. This may influence the way Norwegian students express themselves in English, and their awareness of what is appropriate may not be as developed in English as in Norwegian.

Another explanation for the informal, personal style many Norwegian students use when writing can be explained by the fact that in the Norwegian school system, there is a clear preference for narratives, which requires a different type of writing than argumentative writing. The students starting in upper secondary school come from a tradition where writing texts with involvement and using a personal style has been encouraged (Øgreid \& Hertzberg, 2009, p. 458). Interviews carried out to follow up on the current study indicate that the students had not learnt much about writing argumentative texts and using formal language before upper secondary school (Horverak, 2016b). Keeping this in mind, it is not surprising that the students struggle when met with totally different expectations in upper secondary school.

I would argue that the challenges revealed in this study call for a type of writing instruction pedagogy that focuses on how to teach students to structure texts properly, and how to adjust language to context. I would also suggest that genre pedagogy as developed in Australia based on systemic functional linguistics (Cope \& Kalantzis, 2012) offers such an approach. This type of instruction has shown to be useful in the teaching of how to write in various contexts (Humphrey \& Macnaught, 2015; Rose, Rose, Farrington, \& Page, 2008; Walsh, Hammond, Brindley, \& Nunan, 1990; author) In this pedagogy, there are three main 


\section{Nordic Journal of Modern Language Methodology}

elements 1) deconstruction of model texts to investigate typical linguistic features and structure of texts, 2) joint construction where teacher and students write texts together based on model texts and 3) independent construction of text with support from teacher through feedback. Based on the material in the current study, it seems to be problematic to structure text and adjust language to context. There is a need for a type of writing instruction approach that helps students learn this, and as I demonstrate in the quasi-experimental study on which the current study is based (Horverak, 2016a), a genre-pedagogical approach to teaching writing may give students support to improve their argumentative writing in English.

\section{CONCLUSION}

This study has explored what problems Norwegian upper secondary school students face when meeting the demands of writing argumentative texts in English when transferring from lower to upper secondary school. The material collected in this study suggests that students struggle with structuring texts, writing thorough arguments and discussions by referring to sources properly, and adjusting the language in terms of modality and formality level. These are all elements that are central in genre-pedagogy. Hence, I would advocate implementing a teaching approach based on genre-pedagogy to help students improve their ability to write argumentative texts.

As this study is based on a rather limited sample, there is a need to investigate further what type of challenges Norwegian students in upper secondary school have when writing in English. Another context in which research is needed in Norway is lower secondary school; what problems do pupils on lower levels face when writing in English, how is English writing instruction carried out in lower secondary school and what type of texts do pupils on this level write to prepare for future requirements? English writing and writing instruction is an underresearched area in a Norwegian context, and with increasing demands of English skills in society in general, this is an area that needs attention.

\section{LITERATURE}

Andrews, R. (1995). Teaching and learning argument. London: Cassel.

Beard, R. (2000). Developing writing 3-13. London: Hodder Stoughton.

Berge, K. L., Evensen, L. S., Hertzberg, F., \& Vagle, W. (Eds.). (2005). Ungdommers skrivekompetanse Norskeksamen som tekst Bind 2. Oslo: Universitetsforl. 
Berge, K. L., \& Hertzberg, F. (2005). Ettertanker - og tanker om framtidas utfordringer. In Ungdommers skrivekompetanse Norskeksamen som tekst Bind 2 (pp. 387-393). Oslo: Universitetsforl.

Biber, D. (1988). Variation across speech and writing. Cambridge: Cambridge University Press.

Bonnet, G. (2004). The assessment of pupils' skills in English in eight European countries 2002. Retrieved from

Byrnes, H., \& Manchón, R. (2014). Task-based language learning : insights from and for L2 writing (Vol. 7). Amsterdam: John Benjamins.

Cohen, L., Manion, L., \& Morrison, K. (2011). Research methods in education. London: Routledge.

Cope, B., \& Kalantzis, M. (2012). The powers of literacy, a genre approach to teaching writing. London Washington: The Falmer Press.

Education First. (2012). EF English Proficiency Index (EF EPI). 3rd ed. Retrieved from http://www.ef.no/epi/

European Parliament. (2006). Recommendation of the European Parliament and of the Council of 18 December 2006 on key competences for lifelong learning. Retrieved from http://eur-lex.europa.eu/legal-

content/EN/ALL/ELX_SESSIONID=kCSXT26P5ylxfKrhyvwXwC59pQpPMNMdxnh N6FMgwbGj3bTTt5rs!-1556749933?uri=CELEX:32006H0962

Freedman, A., \& Pringle, I. (1988). Why students can't write arguments. In N. Mercer (Ed.), Language and literacy from an educational perspective (Vol. II: In Schools, pp. 233242). Milton Keynes: Open University Press.

Graddol, D. (1997). The future of English. London: The British Council.

Graddol, D. (2006). English next (Vol. 62): British Council London.

Hellekjær, G. O. (2007). The Implementation of Undergraduate Level English Medium Programs in Norway: An Explorative Case Study. In R. Wilkinson \& V. Zegers (Eds.), Researching content and language integration in higher education (pp. 68-81). Maastricht University Language Centre.

Hellekjær, G. O. (2010). Lecture comprehension in English-medium higher education. Hermes-Journal of Language and Communication Studies, 45, 11-34.

Horverak, M. O. (2015). Feedback practices in English in Norwegian upper secondary schools. Nordic Journal of Modern Language Methodology, 3(2).

Horverak, M. O. (2016a). An experimental study on the effect of systemic functional linguistics applied through a genre-pedagogy approach to teaching writing. Yearbook of the Poznan Linguistic Meeting, 2(1), 67-89. doi:https://doi.org/10.1515/yplm-20160004

Horverak, M. O. (2016b). Students' and teachers' perceptions on writing instruction inspired by genre-pedagogy and systemic functional linguistics. In L. Veselovská, J. K. Parrott, \& M. Janebová (Eds.), Proceedings of the 5th Central European Conference in Linguistics for Postgraduate Students (pp. 58-73). Olomouc: Palacký University.

Humphrey, S., \& Macnaught, L. (2015). Functional language instruction and the writing growth of English language learners in the middle years. TESOL Quarterly.

Hundahl, A. K. (2010). Mellom setning og tekst. Tematisk organisering i elvtekster fra 4. og 7. trinn. In J. Smidt, I. Folkvodr, \& A. J. Aasen (Eds.), Rammer for skriving: Om skriveutvikling i skole og yrkesliv (pp. 51-64). Trondheim: Tapir akademiske forlag. 
Kuiken, F., \& Vedder, I. (2002). The effect of interaction in acquiring the grammar of a second language. International Journal of Educational Research, 37(3-4), 343-358. doi:10.1016/S0883-0355(03)00009-0

Lehmann, T. M. (1999). Literacy and the tertiary student: why has the communicative approach failed? , T.M. Lehmann, Bergen.

Leki, I., Cumming, A., \& Silva, T. (2008). A synthesis of research on second language writing in English. New York: Routledge.

Mehta, S. R., \& Al-Mahrooqi, R. (2015). Can thinking be taught? Linking critical thinking and writing in an EFL context. RELC Journal: A Journal of Language Teaching and Research, 46(1), 23-36. doi:10.1177/0033688214555356

Norwegian Directorate for Education and Training. (2006). Læreplanverket for Kunnskapsløftet midlertidig utgave. Retrieved from http://www.udir.no/upload/larerplaner/Fastsatte_lareplaner_for_Kunnskapsloeftet/Kunn skapsloftet_midlertidig_utgave_2006_tekstdel.pdf

Norwegian Directorate for Education and Training. (2013a). English subject curriculum. Retrieved from http://www.udir.no/k106/ENG1-03/Hele/?lplang=eng

Norwegian Directorate for Education and Training. (2013b). Sensorveiledning i engelsk. Retrieved from http://www.udir.no/Upload/Eksamen/Videregaende/H12/ENG1002og1003_Engelsk\%2 Ofellesfag_Sensorveiledning_H12_BM.pdf

Norwegian Directorate for Education and Training. (2014). Skoleporten Læringsresultater. Retrieved from https://skoleporten.udir.no/rapportvisning.aspx?enhetsid=00\&vurderingsomrade $=11 \& \mathrm{u}$ nderomrade $=21 \&$ skoletype $=0 \&$ skoletypemenuid $=0$

Nygaard, A. M. (2010). An investigation of accuracy in the written English of upper secondary vocational school students. (Master's degree), University of Stavanger, Norway,

Rindal, U. (2012). Meaning in English, L2 attitudes, choices and pronunciation in Norway. (PhD Thesis), Oslo,

Rindal, U., \& Piercy, C. (2013). Being 'neutral'? English pronunciation among Norwegian learners. World Englishes, 32(2), 211-229.

Robinson, P. (2001a). Task complexity, cognitive resources, and syllabus design: A triadic framework for examining task influences on SLA. In P. Robinson (Ed.), Cognition and second language instruction (pp. 287-318). Cambridge: Cambridge University Press.

Robinson, P. (2001b). Task complexity, task difficulty, and task production: Exploring interactions in a componential framework. Applied Linguistics, 22(1), 27-57. doi:10.1093/applin/22.1.27

Rose, D. (2009). Writing as linguistic mastery: The development of genre-based literacy. In R. Beard (Ed.), The SAGE handbook of writing development (pp. 151-166). London: SAGE.

Rose, D., Rose, M., Farrington, S., \& Page, S. (2008). Scaffolding academic literacy with indigenous health sciences students: An evaluating study. Journal of English for Academic Purposes, 7(3), 165-179. doi:10.1016/j.jeap.2008.05.004

Ruiz-Funes, M. (2015). Exploring the potential of second/foreign language writing for language learning: The effects of task factors and learner variables. Journal of Second Language Writing, 28, 1-19. doi:10.1016/j.jslw.2015.02.001 
Shaw, S. D., \& Weir, C. J. (2007). Studies in language testing, 26, examining writing. Uk: Cambridge University Press.

Silva, T. (1993). Toward an understanding of the distinct nature of L2 writing: The ESL research and its implications. TESOL Quarterly(27), 657-677.

Skehan, P. (1998). A cognitive approach to language learning. Oxford: Oxford University Press.

Vygotsky, L. S., Hanfmann, E., \& Vakar, G. (2012, first published in 1962). Thought and language. Cambridge, Mass: M.I.T Press.

Walsh, J., Hammond, J., Brindley, G., \& Nunan, D. (1990). Metropolitan East Disadvantaged Schools Program; Factual writing project evaluation. Retrieved from

Øgreid, A. K., \& Hertzberg, F. (2009). Argumentation in and across disciplines: two Norwegian cases. Argumentation, 23(4), 451-468.

\section{Appendix 1}

\section{EVALUATION CRITERIA:}

\begin{tabular}{|l|l|}
\hline Structure & Grade 1-6 \\
\hline $\begin{array}{l}\text { Introduction: How well is the topic and question for discussion/thesis } \\
\text { statement presented? }\end{array}$ & \\
\hline Paragraph-division: How well are the ideas sorted into paragraphs? & \\
\hline $\begin{array}{l}\text { Topic sentences: How well are the arguments in the paragraphs presented } \\
\text { through the topic sentences in the paragraphs? }\end{array}$ & \\
\hline $\begin{array}{l}\text { Coherence of arguments: How clear is the writer's opinion throughout the } \\
\text { discussion? }\end{array}$ & \\
\hline $\begin{array}{l}\text { Conclusion: How well does the final paragraph sum up the arguments and } \\
\text { give a clear conclusion/answer to the question for discussion? }\end{array}$ & \\
\hline $\begin{array}{l}\text { Cohesive links: How well is the content logically linked by the use of } \\
\text { connectors? }\end{array}$ & \\
\hline $\begin{array}{l}\text { Cohesive links: How well is the content logically linked by the use of } \\
\text { pronouns? }\end{array}$ & \\
\hline Total evaluation of structure & \\
\hline
\end{tabular}

\begin{tabular}{|l|l|}
\hline Language & Grade 1-6 \\
\hline Spelling: To what extent is the spelling correct? & \\
\hline Grammar: To what extent is the grammar correct? & \\
\hline $\begin{array}{l}\text { Sentence complexity: To what degree does the student use complex sentence } \\
\text { structure? }\end{array}$ & \\
\hline $\begin{array}{l}\text { Vocabulary: To what extent does the student show an advanced and varied } \\
\text { vocabulary? }\end{array}$ & \\
\hline $\begin{array}{l}\text { Formality level: To what degree does the student use the appropriate formality } \\
\text { level of language? }\end{array}$ & \\
\hline $\begin{array}{l}\text { Modality: To what extent does the student express degrees of possibility and } \\
\text { uncertainty in a good way? }\end{array}$ & \\
\hline
\end{tabular}




\section{Total evaluation of language}

\begin{tabular}{|l|l|}
\hline Content & Grade 1-6 \\
\hline $\begin{array}{l}\text { Exercise - topic: How well does the text answer the question in the exercise } \\
\text { given? }\end{array}$ & \\
\hline Topic: How clear is the topic for discussion in the text? & \\
\hline Relevance: To what degree are the arguments included relevant to the topic? & \\
\hline Thoroughness: How detailed and thorough is the argumentation? & \\
\hline $\begin{array}{l}\text { Discussion: To what degree does the text show different opinions or counter- } \\
\text { arguments? }\end{array}$ & \\
\hline $\begin{array}{l}\text { Sources: How well does the student use sources in a sensible and independent } \\
\text { way? }\end{array}$ & \\
\hline $\begin{array}{l}\text { Literature: How well are the sources referred to in the running text and in a } \\
\text { literature list? }\end{array}$ & \\
\hline Total evaluation of content & \\
\hline
\end{tabular}

TOTAL EVALUATION: 